\title{
Candor est lucis aeternae: the "Transfiguration" of a New Feast and of an Alleluia'
}

\author{
Gábor KISS \\ Institute of Musicology \\ Research Centre for the Humanities \\ Hungarian Academy of Sciences \\ Táncsics Mihály u. 7, H-1014 Budapest, Hungary \\ E-mail: kiss.gabor@btk.mta.hu
}

(Received: February 2015; accepted: April 2015)

\begin{abstract}
The introduction of new feasts was regularly accompanied by a kind of rearrangement of the liturgical material. In the beginning Transfiguratio Domini was not obligatory feast, but was introduced gradually in more and more churches from the 10th century on. During the greater part of its history it had no special Proper for the mass, but different chants were drawn from the masses of traditional feasts, like Christmas, Epiphany, the Easter season and even the Holy Trinity. In the sources that include at all a mass for Transfiguratio we see different sets of Proper chants, borrowed from different feasts. The status of the feast changed when pope Callixtus III extended the feast to the Universal Church in memory of the victory gained by the Hungarians over the Turks. After that a new Proper was compiled, which, however, was slowly adopted by the different dioceses. It is questionable whether new melodies were also composed or the texts were sung to existing melodies instead. In Hungary the feast understandably gained special importance and apparently there was a need for Proper melodies. Since, however, there were no ordered melodies (or they were not at hand), every scriptor had to compose or find their own version. The paper demonstrates a great variety of solutions through the different melodies set to the Alleluia text Candor est lucis.
\end{abstract}

Keywords: Transfiguratio, Proper chants, Alleluia, Hungary, adaptation, properization

The rise and introduction of newer Christian feasts went generally together with a certain rearrangement and renewal of the liturgical material which may have taken place in various ways. The simplest mode of instituting an additional saint

1. The paper was given at the conference In memoriam László Dobszay at the Institute of Musicology, Budapest on 31 January 2015. This research was supported by the Hungarian Scientific Research Fund (K 81763, NK 104426). 
or a new calendar feast was to select adequate, already available items from the Common of Saints. It was just a step from this selection performed with a certain freedom to compose a new melody or at least to adapt a new text to an earlier melody. Another possibility was to create a new combination of existing texts and melodies. The fact that the two constituents of liturgy: text and melody represent different phenomena and can (also) be interpreted on different levels opened the possibility of treating them to a certain extent independently from each other. In point of fact, the liturgy could remain "unimpaired" irrespective of the melodic changes, whereas the melodic component could carry liturgical contents and create associations, not to speak of meeting other, for example aesthetic requirements. The combination and interaction of these two layers brought about a diversity of liturgical systems and customs embedded in the local culture that entailed definite consequences of method for the research of liturgy.

It depended on a great many things which of the above factors prevailed at the time of introducing a new feast: the traditions of the genre, the intentions, the local conditions, or external factors such as cultural influences and, last but not least, on the customs, trends, taste and needs of a given period. Although the observation of the feast of the Transfiguration of the Lord was not generally ordered at the beginning, from the $10^{\text {th }}$ century on it was celebrated in more and more places. (According to certain views its spread was not independent from the eschatological expectations at the turn of the century. $)^{2}$ The feast had no Proper of its own for a long time, during most of its observance in the Middle Ages. Given the nature of the feast, its items were not taken from the Common of Saints, even though a technically similar procedure was followed, namely a selection from different places, the greater feasts of the Temporale was made. ${ }^{3}$ It depended largely on the traditions and sources which feasts were taken into consideration and what kind of a cycle was formed of the borrowed items.

The majority of the items were generally taken from Christmas; even an arrangement exists in which each item derives from some Christmas Mass (Graduale Horaždovice). ${ }^{4}$ It is, however, a rare exception when all items originate in the same place. The printed Missal of Trier is, for example, of the kind: apart from the sequence the whole first Mass at Christmas is repeated (Missale Trevirense

2. Sándor Bálint, Ünnepi kalendárium II. A Mária-ünnepek és jelesebb napok hazai és közép-európai hagyományvilágából [Calendar of feasts II. From the tradition of Marian feasts and other important feasts in Hungary and Central Europe] (Budapest: Szent István Társulat, 1977), 157-164, notes: 239-240; Albert Paretsky, "The Transfiguration of Christ: its Eschatological and Christological Dimensions," New Blackfriars 72 (1991), 313-324.

3. As Balázs Déri's study on the Esztergom/Gran liturgy of the feast demonstrates, it is partly true of the non-musical items as well. Cf. Balázs Déri, "Színeváltozás ünnepe az 1484-es, nyomtatott Esztergomi misekönyvben" [The Feast of the Transfiguration in the 1484 printed Missal of Esztergom], Magyar Egyházzene 18 (2010/2011), 301-308.

4. CZ-HORm Sg. 487, f 115 bis. 
1547). ${ }^{5}$ At certain points other sources may also have been taken into consideration as an option: for an entrance, for example, the Introit of the Mass on Sunday after Epiphany (In excelso trono) was returned to in several places (Augsburg, Freising, Passau, Regensburg, Salzburg, the Premonstratensian canons regular of Strahov). ${ }^{6}$ The Gradual derives in several instances, though not too frequently, from Sunday within the octave of Christmas, thus also in Esztergom (e.g. Missale Notatum Strigoniense). ${ }^{7}$ Based on the above, it may already be claimed that the $14^{\text {th }}$-century Esztergom practice was rare, at least concerning the choice of the Gradual. ${ }^{8}$ Items from Easter Week also occur sporadically (where the agreement between the solutions of the Hungarian and the Premonstratensian sources can again be seen). It is worth noting that despite the reuse of this traditional material hardly any completely identical sources or traditions can be found (see Table 1; the sources containing identical Propers have been gathered in one column). ${ }^{9}$ The choice of the Offertory and the Communion seems relatively stable (even if with exceptions) and the Alleluia Dies sanctificatus (an item of the main Christmas Mass) is very often used; nonetheless, almost each arrangement varies (Table 1).

Some of the sources include among the Propers, originating in the above mentioned places, the sequence for the Feast of Trinity (Benedicta semper sit sancta Trinitas or St. Victor's Profitentes unitatem) ${ }^{10}$ or its Alleluia (Benedictus es Domine) as well (e.g. in the Brandenburg Missal). Moreover, several traditions

5. Missale Trevirense, Coblenz 1547, f 221.

6. E.g. Missale Augustense, [Basel] 1510, f 170 (D-Mbs 2 Liturg. 185a); Missale Freisingense 1502, f 199v (D-Mbs Rar. 2090); Graduale Pataviense, Wien 1511, f 133, cf. its facsimile edition: Graduale Pataviense, Wien 1511, ed. Christian Väterlein (Kassel: Bärenreiter, 1982); Missale Pataviense, Nürnberg 1514, f 243 (D-Mbs Rar. 2285); Missale Ratisbonense 1485, f 240 (D-Mbs Rar. 67); Missale Salzburgense saec. 15 (H-SY Cod. 2), f 193; Graduale Premonstratense saec. 17 (CZ-Pst DF V 51), f 66v. The Paduan practice used, based on the evidence of the $13^{\text {th }}$-century Paduan Liber Ordinarius (f $134 \mathrm{v}$ ), the complete In excelso trono Mass for celebrating the Feast of the Transfiguration. Cf. Il "Liber Ordinarius" della Chiesa padovana. Padova, Biblioteca Capitolare, ms. E 57, sec. XIII, eds Giulio Cattin et al. (Padova: Istituto per la Storia Ecclesiastica Padovana, 2002).

7. Missale Notatum Strigoniense, ante 1341 (SK-BRm EC Lad. 3), f 261.

8. So far it has only been found in the Printed Missal of Brandenburg 1494 (D-B $2^{\circ}$ Inc 1909a) and the Premonstratensian Gradual mentioned above, whereas the 1511 Graduale Pataviense indicates it as an alternative item. It is to be remarked that it was also incorporated into the Roman practice (at a time when in Esztergom another solution was already used) but in the early copies of that the verse occurs with a shorter text.

9. The sources used for Table 1 are: Strigonium: SK-BRm EC Lad. 3, H-Bn Clmae 359; PL-Plsem s. sign; CZ-HORm Sg. 487; Missale Sarum, Paris 1521, http://gallica.bnf.fr/ark:/12148/bpt6k52953j.r; Missale Carmelitarum 1490, http://gallica.bnf.fr/ark:/12148/bpt6k5578012t; Beneventan: I-BV 34, 35, 38, 39, 40, cf. Beneventanum Troporum Corpus I, Tropes of the Proper of the Mass from Southern Italy, A.D. 1000-1250, ed. Alejandro Enrique Planchart (Madison: A-R Editions, 1994), 14; Missale Pictavense, Paris 1498 (F-Psg OEXV 163 RES); Missale Magdeburgense, Nürnberg 1503 (D-Mbs Res/2 Liturg. 451 k); Missale Nivernense, Paris 1490 (F-Psg OEXV 619 RES); Missale Augustense 1510 (D-Mbs Rar. 2102); Missale Aquense 1466 (F-Pnm NAL 2661); Passau: Graduale Pataviense, Wien 1511, Missale Pataviense, Nürnberg 1514; Missale Frisingense 1502 (D-Mbs Rar. 2090); Missale Ratisbonense 1485; Missale Salzburgense saec. 15; Missale Brandenburgense 1494; Graduale ex Braga 1510-1515 (P-BRs Ms. 34); Graduale Premonstratense saec. 17; Missale Trevirense 1547.

10. The sequence appears in the Gradual of Braşov II (RO-Sb Ms. 759, f 103v) exceptionally among the Hungarian sources. 
TABLE 1 The Proper for Transfiguratio Domini - Phase I

\begin{tabular}{|c|c|c|c|c|c|c|}
\hline & Introit & Gradual & Alleluia & Sequence & Offertory & Communion \\
\hline Strigonium I. s. 14, 15 & Nat/M2 & $\begin{array}{l}\text { D/Oct. } \\
\text { Nat }\end{array}$ & Nat/M3 & & $\begin{array}{l}\text { Pasc/H1/ } \\
\text { f3 }\end{array}$ & Nat/M1 \\
\hline Plock s. $14 / 15$ & Ep/D1 & Nat/M1 & Nat/M3 & & Nat/M2 & Nat/M1 \\
\hline Horaždovice s. 15/ex & Nat/M2 & Nat/M1 & Nat/M3 & Trin & Nat/M2 & Nat/M1 \\
\hline Sarum 1521 & Adv/QuT & Nat/M1 & Nat/M3 & Pasc & Nat/M2 & Nat/M1 \\
\hline Carmelites 1490 & Nat/M1 & Nat/M1 & Nat/M3 & & Nat/M2 & Nat/M1 \\
\hline Beneventan s. 11/12 & Trin & Trin & Trin & Trin & Trin & Trin \\
\hline $\begin{array}{l}\text { Poitiers } 1498 \\
\text { Magdeburg } 1503 \\
\end{array}$ & Trin & Trin & Trin & Trin & Trin & Trin \\
\hline $\begin{array}{l}\text { Nevers } 1490 \\
\text { Augsburg } 1510\end{array}$ & Ep/D1 & Nat/M1 & Nat/M3 & Trin & Nat/M2 & Nat/M1 \\
\hline Aix-en-Provence 1466 & Nat/M1 & Nat/M3 & Transfig & & Nat/M1 & Nat/M1 \\
\hline $\begin{array}{l}\text { Passau 1511, } 1514 \\
\text { Freising } 1502\end{array}$ & Ep/D1 & Nat/M2 & Nat/M2 & Transfig & Nat/M2 & Nat/M1 \\
\hline $\begin{array}{l}\text { Regensburg } 1485 \\
\text { Salzburg s. 15/ex }\end{array}$ & Ep/D1 & Nat/M2 & Transfig & Transfig & Nat/M2 & Nat/M1 \\
\hline Brandenburg 1494 & Nat/M1 & $\begin{array}{l}\text { D/Oct. } \\
\text { Nat }\end{array}$ & Trin & & C.m. & Nat/M3 \\
\hline Braga 1510 & Nat/M1 & Nat/M1 & Transfig & & Nat/M2 & Nat/M1 \\
\hline Strahov s. 17 & Ep/D1 & $\begin{array}{l}\text { D/Oct. } \\
\text { Nat }\end{array}$ & Nat/M3 & & $\begin{array}{l}\text { Pasc/H1/ } \\
\text { f3 }\end{array}$ & Nat/M1 \\
\hline Trier I 1547 & Nat/M1 & Nat/M1 & Nat/M1 & Ep & Nat/M1 & Nat/M1 \\
\hline
\end{tabular}

are known where on 6 August the complete Missa sancti Trinitatis is repeated (Poitiers, Magdeburg). It is to be noted that contrary to all other Hungarian partial traditions, the 1499 Missal of Pécs ${ }^{11}$ also relies on the Proper of Trinity in this place. It is unclear what kind of considerations may have initiated the tradition of linking these two feasts. Thomas Aquinas's interpretation of the scene of the Transfiguration of Christ on Mount Tabor in the third volume of Summa theologica must have been widely known, according to which the entire Holy Trinity was present there: Jesus, the Father represented by a voice from heaven (vox de nube) and the Holy Spirit who appeared in a "bright cloud" (nubes lucida). ${ }^{12}$ It

11. Missale Quinqueecclesiense, Venezia 1499 (H-Bn RMK III/52 +), f 214v).

12. Matth. 17: 5. “... ita etiam in transfiguratione, quae est sacramentum secundae regenerationis, tota Trinitas apparuit, pater in voce, filius in homine, spiritus sanctus in nube clara ...", Summa Theologica III, Quaestio 45, Articulus 4, Sancti Thomae Aquinatis Doctoris Angelici Opera Omnia Iussu Impensaque Leonis XIII P. M. Edita (Roma: Ex Typographia Polyglotta, 1903), 433; https://archive.org/stream/operaomniaiussui11thom\#page/n5/mode/2up. Oliver Messiaen's oratorio La Transfiguration De Notre Seigneur Jesus Christ, 
is unknown whether there was such a popular explanation at all but St. Thomas Aquinas's commentary, which Oliver Messian was so fond of, cannot have exerted a direct influence on linking the two feasts because the same liturgical borrowing already appears in $11^{\text {th }}-12^{\text {th }}$-century Beneventan sources as well.

The Feast of the Transfiguration was not observed everywhere and seems to have been entered into the sources in some places only. The non-exhaustive material compiled however from a wide range of sources required the examination of a far more abundant stock, including the sources omitting the feast. Conclusions for the practice of the various dioceses have sometimes been drawn from printed sources regarded as retrospective and codifying in all probability the valid tradition. An obvious change in the status of the feast must have been when Pope Callistus III ordered the general observation of the Feast to commemorate the victory at Nándorfehérvár (now Belgrade) since news of the victory reached Rome on 6 August, the Feast of the Transfiguration. ${ }^{13}$ From the second half of the $15^{\text {th }}$ century on, sources without the feast are more and more scarce. After that time a new Proper of the feast was made, ${ }^{14}$ but it was not put into use overnight, if at all. The change of the status of the feast and the renewal of its Proper can be excellently traced in the Diocese of Esztergom as demonstrated palpably in the case of the 1484 printed Missal of Esztergom by Balázs Déri. It allows us to follow the shift of the position of the feast (from appendix to the main text) and the coexistence of the old and new Propers. ${ }^{15}$

There is no knowledge how it happened elsewhere but the sources reflect the "official" and "unofficial" periods of the feast in a contradictory manner. On the one hand, we can see that in certain traditions the new repertory did not replace the old one, nor did it appear as an alternative in the appendix long after the compulsory observance of the feast had been ordered. In this respect the case of Trier is particularly telling where the mid- $16^{\text {th }}$-century printed Missal still contained the early Proper and the new edition of half a century later took only over a part of the by then widely-spread new items (see Table 1 and 2). ${ }^{16}$ At any rate, there is

in which apart from words taken from the Gospel, passages from St. Thomas's work can also be found and the penultimate item of which is entitled Tota Trinitas apparuit, combines the two feasts and concepts based on St. Thomas Aquinas.

13. About the origin, content and introduction of the feast see: "Verklärung Christi," in Lexikon für Theologie und Kirche, Bd. 10 (Freiburg im Breisgau: Herder, 1938), 562-563; Suitbert Bäumer, Geschichte des Breviers. Versuch einer quellenmässigen Darstellung der Entwicklung des altkirchlichen und des römischen Officiums (Freiburg im Breisgau: Herder, 1895), 380. The papal bull of Callistus III is published in Bullarium ... Romanorum pontificum amplissima collectio, ed. Carolus Coquelines (Graz: Akademische Druck- und Verlangsanstalt, 1733), vol. III, 3, no. 84.

14. Intr. Viderunt ingressos tuos, Gr. Cantate Domino et benedicite nomini eius, All. Candor est lucis, Off. Gloria et divitiae in domo eius, Comm. Viderunt omnes fines terrae ... alleluia.

15. Déri, "Színeváltozás"; cf. Missale Strigoniense, id est Missale secundum almae ecclesiae Strigoniensis, impressum Nurenbergae apud Anthonium Koburger, anno Domini MCCCCLXXXIIII, ed. Balázs Déri (Budapest: Argumentum Kiadó, 2009), XXV-XXVI and XLII-XLIII.

16. The sources used for Table 2 are: Strigonium II: H-Efkö MS I. 1 a-b; TR-Itks 2429; H-Bn Fol. Lat. 3815; Missale Vratislaviense 1483 (H-Bn Inc. 66), PL-Wru M 1194; Missale Coloniense, Köln 1494 (D-Mbs 
a certain insecurity of interpretation in this instance, which is due to the scarce number of the earlier recordings of the feast. Even though there are examples when handwritten sources corroborate the evidence of the contents of the printed editions, it is not sure that the contents of the latter can generally be traced back to the earlier practice. It cannot be precluded that the omission of the feast from the sources is all but accidental indicating its omission from practice as well. Only after the general observance of the feast was it entered into the prints and its items were selected according to the traditional method, due perhaps to the fact that its new Proper was not available everywhere (Table 2).

On the other hand, already besides the use of unofficial sets of Proper cycles (and probably unaware of the existence of a new one) a kind of partial "properization" started to take place in the material of the feast, that is the well-known items of the standard repertoire were supplemented by special items associated explicitly with the feast. It is not by chance that the items in question were Sequences and Alleluias playing an important part in the later growth of the repertoire as well, particularly items used in a well-confined, relatively narrow region. The text of the Sequence beginning with the words Speciosus forma prae natis hominum Jesus is not a borrowing; its use is restricted to the Feast of the Transfiguration alone (see Table 1; the appropriate places are highlighted by shading). According to Analecta Hymnica ${ }^{17}$ and my own research, it appears exclusively in the sources of the south German-Austrian-Czech territories after the $12^{\text {th }}$ century (columns with Passau, Freising, Regensburg, Salzburg)..$^{18}$ From the $15^{\text {th }}$ century two cases are known where the relevant passage of the Gospel according to St. Matthew is applied with a feast-related Alleluia text, what is more, with a new melody. The Alleluia Hodie Jesus Christus facie resplenduit is known from only a few sources on south German areas (column Regensburg, Salzburg). No other function of the traditionally-styled item, which is also available in the complete edition of Alleluias ${ }^{19}$ is known. By contrast, Ascendit Jesus in montem originates in the western region and cannot have been widely spread: so far it has merely emerged in two sources, a French and an Aquitaine one (columns Aix-en-Provence and

2 L.impr.membr. 72); Missale Andegavense, Paris 1489 (F-Psg OEXV 598 RES); Missale Paulinorum c. 1506 (PL-CZ sygn. III-3, olim. R. 589); RO-Sb Ms. 759; HR-Zmk MR 6; Missale Trevirense, Trier 1608 (D-KBrlb 2002A/123 P-SOM); Missale Lugdunense, Lyon 1688: https://books.google.hu/books?id=mPa6eg1Z1KgC\&printsec $=$ frontcover\&dq=missale+lugdunensis\&redir_esc $=y \# v=$ onepage \& $q=$ missale $\% 201$ gdunensis\&f=false; Missale Ambrosianum, Milano 1712 (D-Mbs Res/2 Liturg. 182).

17. Analecta Hymnica Medii Aevi, vol. 50, Hymnography Latini. Lateinische Hymnendichter des Mittelalters, ed. Guido Maria Dreves (Leipzig: O. R. Reisland, 1907), 354.

18. However, its melody is not new but borrowed from the melody of the widely spread sequence Eja recolamus. Through it, it is partly attached to the earlier practice as the latter is a constituent of the second Mass at Christmas, cf. Lateinische Sequenzen des Mittelalters, ed. Karl Bartsch (Rostock: Stiller'sche Hof-Buchhandlung, 1868), 15, 118.

19. Alleluia-Melodien II ab 1100, ed. Karlheinz Schlager (Kassel-Basel, etc.: Bärenreiter, 1987) (= Monumenta Monodica Medii Aevi 8), 212, 659. 
TABle 2 The Proper for Transfiguratio Domini - Phase II

\begin{tabular}{|l|l|l|l|l|l|l|}
\hline & Introit & Gradual & Alleluia & Sequence & Offertory & Communion \\
\hline Strigonium II. s. 15, 16 & Transfig & Transfig & Transfig & Transfig & Transfig & Transfig \\
\hline Wrocław 1483 & Transfig & Transfig & Transfig & Transfig & Transfig & Transfig \\
\hline Köln 1494 & Transfig & Transfig & Transfig & Transfig & Transfig & Transfig \\
\hline Angers 1489 & Transfig & Transfig & Transfig & Transfig & Transfig & Transfig \\
\hline Pauline 1506 & Transfig & Transfig & Transfig & Transfig & Transfig & Transfig \\
\hline Braşov s. 16/in & Transfig & Nat/M3 & Transfig & Transfig & Transfig & Transfig \\
\hline Zagreb s. 18 & & Transfig & Transfig & & Transfig & Nat/M3 \\
\hline Trier II 1608 & Nat/M1 & Nat/M1 & Transfig & Ep & Transfig & Transfig \\
\hline Lyon 1688 & Transfig & Transfig & Transfig & Transfig & Transfig & Transfig \\
\hline Ambrosian 1712 & Transfig & Transfig & Transfig & Transfig & Transfig & Transfig \\
\hline
\end{tabular}

Braga) ${ }^{20}$ The Utraquist sources represent a special case of properization and at the same time of the free shaping of the late repertoire. The strange set comprises several layers: a traditional item (Gr. Viderunt omnes), new texts, paraphrases, the adaptation of psalms to newly composed melodies or at least to ones not known from anywhere else so far (Intr. Quem angelus a Deo, Comm. In monte mandavit Dominus) and their adaptation to the most traditional melodies used in this function as well (All. Qui sapissine manibus, melody: Laetabitur iustus, ${ }^{21}$ All. Duxit res discipulos Iesus, melody: Dies sanctificatus). ${ }^{22}$

As the table shows, the new Proper spread in the overwhelming majority of cases as a cycle except for the few instances when old and new Proper items intermingled. The cycle means in this context texts alone. It is highly questionable whether the newly composed melodic material emerged simultaneously with wording the text and if so, whether it reached the people shaping the local liturgies or the decision was left to them what kind of melody the compulsory texts should be sung to. For lack of an adequate number of late manuscript sources with melodies (the printed Missals omitted namely the melodies), we can often conjecture only what kind of melodies featured in the actual practice of the various traditions. As mentioned in the introduction, the individual formation of the melodic constituent can increase the number of liturgical variants considerably. The scarce source material shows, however, that either there was no such intention or disseminating a melodically homogeneous Proper cycle proved to be a failure. The Hungarian tradition which, for understandable historical reasons, attached great importance to the feast provides a good opportunity for examining the melodies because the material of the feast was entered into no less than eleven sources with considerable differences.

20. Missale Aquense 1466 [p 730]; P-BRs Ms. 34, f 301

21. In the Roman set the words Candor est lucis are sung to the melody of Laetabitur.

22. E.g. Latin Gradual of Klatovy Literary Brotherhood from 1537 (CZ-KLm CS KL 403), f 125. 
In spite of the homogeneous text material no two completely identical cycles can be found. In fact, it is already exceptional when one melody or the other occurs in more than one source. In the three sources of the following example (Graduale Thomae Card. Bakócz, Graduale Francisci de Futhak, Graduale ex Transylvania, see Example 1$)^{23}$ the Proper items have three different melodies although their text is identical. They are by no means distant variants but actually different melodies. The Introit in the Bakócz Gradual is in mode 6, in the Futaki Gradual in mode 1 and in the Transylvanian one in mode 2; the Gradual of the Bakócz Gradual is in mode 5, the Futaki and the Transylvanian ones in mode 1 with a different melody and so forth. The overwhelming majority of the melodies are not borrowed but newly composed ones. It seems to have been evident for the scribes that, contrary to the otherwise prevailing practice, the new texts should not be sung to older melodies. There was in all probability no available model to follow consistently, so the melodies had to be shaped on the spot. Instances of the use of the old techniques can also be found, which further increases variety. The Introit of the Transylvanian Gradual is exceptionally not a new melody but the borrowing of the melody of the Epiphany item Ecce advenit. The choice is all but accidental: as the printed Missal of Nevers ${ }^{24}$ indicates, there had been earlier, at the time of the use of compiled Propers, a practice employing this Introit on the Feast of the Transfiguration. The Transylvanian source adhered to the old practice in the case of the Communion as well, which is a repetition of the item of the Christmas High Mass. ${ }^{25}$ As at this point of the new cycle the traditional text can be found, the lack of melody caused no problem (Example 1). ${ }^{26}$

The systematic survey of the variants of the Alleluia is illustrative, indeed. As the genre constituted the most variable section of the liturgy throughout the Middle Ages and provided the greatest opportunity for creativity, it is extremely interesting to observe what happened to it in the case of a feast introduced so late and under special circumstances. The Alleluia text of the new Proper appears in the second volume of Schlager's complete edition of Alleluias with more than 12 different melodies. ${ }^{27}$ Four are independent tunes documented from one source each. This corroborates what has earlier been said: for lack of a central repertoire the texts were freely provided with melodies, wherever the need arose. The general practice outside Central Europe was to use old melodies: the complete edition presents eight additional solutions where the text Candor est lucis was adapted

23. H-Efkö MS I. 1 a-b; TR-Itks 2429; H-Bn Fol. Lat. 3815.

24. Missale Nivernense, Paris 1490 (F-Psg OEXV 619 RES), f 166v.

25. It is also noteworthy that the Graduale Futhak does not break with the old tradition either: before the new Proper it also lists in rubrics the complete cycle of the earlier Strigonian tradition.

26. It is to be remarked that in the new Proper the Christmas text concludes with the word "alleluia." In spite of the substantial identity of the two texts, the Communion of the Feast of the Transfiguration is given a new melody in the majority of the sources.

27. Schlager, Alleluia-Melodien II, 96-100, 606-607. 


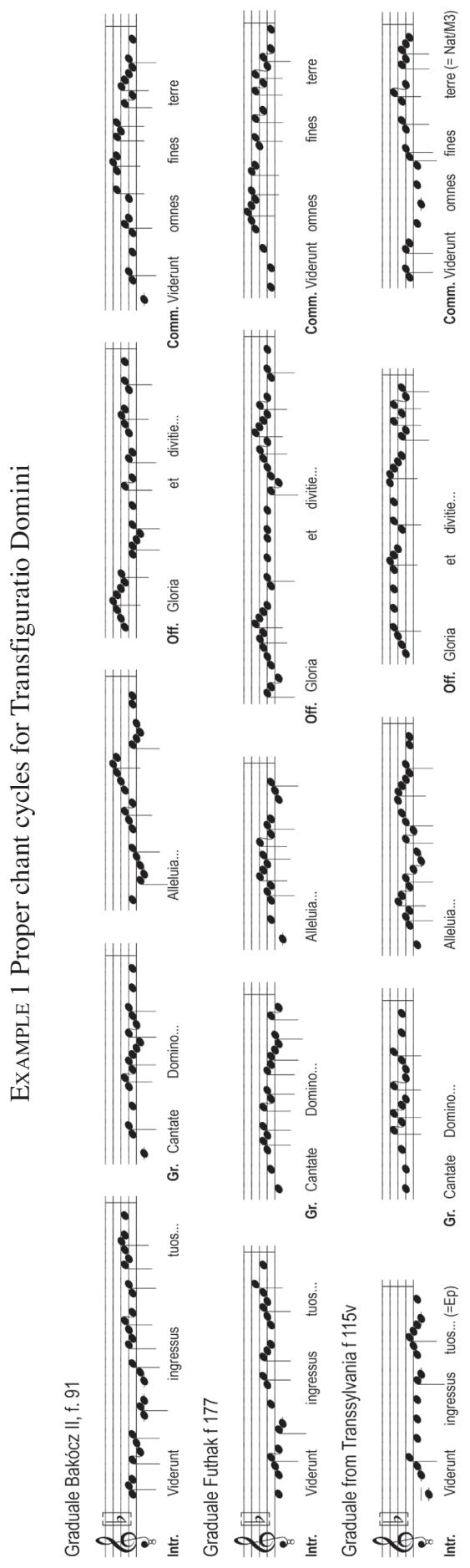


to some well-known melodies. ${ }^{28}$ In view of the wide source basis of the complete Alleluia edition, the number of the sources with independent melodies seems insignificant. In comparison, the zeal of the Hungarian sources is definitely unique in this respect.

It is worth giving an overview of the melodies and the interrelations between them. The earliest melody is the variant of the Graduale de Francisci de Futhak (see Example $2 a$ ), which can be traced back to the $O$ consolatrix pauperum melody group. The eponymous Alleluia was the best-known Marian Alleluia all over Europe in the late Middle Ages; the frequent adaptation of its melody to other texts further increased its style creating force..$^{29}$ The ensuing melodic manner of mode $\mathrm{F}$ was extremely popular in the sources of the Esztergom tradition and its environment. A whole range of Alleluias were composed associated, among others, with Hungarian saints; they employed melodies of modern motives and specific mosaic technique. The result was a melodic group where the melodies were not variants of each other in the strict sense of the word but still felt to have sprung from the same root. ${ }^{30}$

The closest "color variant" ('transfiguration') of this melody adapted to the Feast of the Transfiguration is known from several sources: from Transylvania, the Gradual of Gyöngyöspata and even from a Cracow source, which is for the moment the earliest recording of the melody (see Example $2 b, c, d$ ). ${ }^{31}$ Concerning its place of origin no far-reaching conclusions can however be drawn from it because we must reckon with missing links by all means. It also puts us on guard that while in the sources of Hungary the melody figures as part of and in the chronological order of the complete Proper, the Cracow source contains it with its sequence for the feast in the appended section. Though related to the foregoing melody, it does not show the close connection to that which can be experienced between the melodies of the type $O$ consolatrix. While the latter are characterized by the mosaic-like rearrangement of extremely similar motives, in this instance hardly any well-recognizably similar melodic elements can be found, that is the similarity has less to do with motifs than with reminiscences and can be detected in the stereotypical modes of running through the major tonality (Example 2).

The Bakócz Gradual prescribes two (alternative) Alleluias for the feast. Though they can be associated with the above mentioned manner of melody in the wider

28. Newer melodies: Laetamini in Domino, Tu gloria Ierusalem, Vox exultationis; earlier melodies: Dies sanctificatus, Iusti epulentur, Iustus germinabit, Domine in virtute, Laetabitur iustus.

29. In the complete edition no less than 40 different texts are listed, Schlager, Alleluia-Melodien II, 709710. In the Hungarian tradition several additional texts are known.

30. Cf. Janka Szendrei, "Egy középkor-végi dallamstílus jelentkezése az alleluja-müfajban” [The appearance of a late medieval melodic style in Alleluias], in Zenetudományi Dolgozatok 2004-2005, ed. Márta Sz. Farkas (Budapest: Institute for Musicology, 2005), 107-146; Gábor Kiss, "Egy késő-középkori műfajfüggetlen dallamstílus Közép-Európában" [A late-medieval genre-independent melodic style in Central Europe], in Zenetudományi Dolgozatok 2008, ed. Gábor Kiss (Budapest: Institute for Musicology, 2009), 71-92.

31. H-Bn Fol. Lat. 3815; H-Bn Fol. Lat. 3522; PL-Kk Ms. 45. 


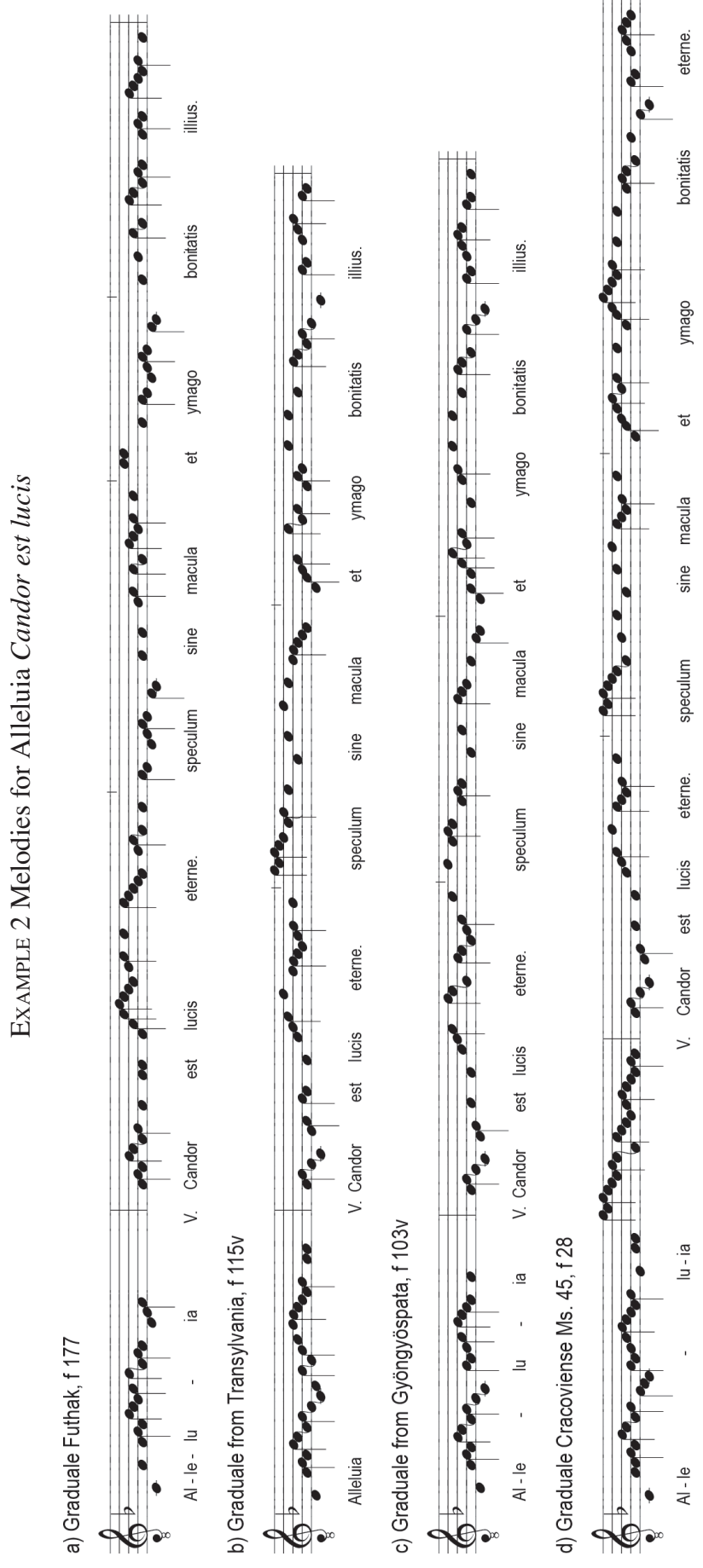

Studia Musicologica 56, 2015 
sense of the word - they belong to its large-range variant combining, so to say, the modes 5 and 6 - both of them differ considerably from the melodies presented so far and from each other. While in the first melody, stereotypical features of the style also emerge despite its unique nature, the extravagant leaps and melismata of the other running through the entire range far exceed the usual stylistic frame (see the extra large range of the highlighted places in Example 3). It is conspicuous that while the Bakócz Gradual is regarded as an authentic summary of the late Esztergom tradition, none of its Alleluias for Transfiguratio appears in other contemporary sources closely linked to Esztergom. By contrast, the first Alleluia occurs elsewhere too, particularly in three sources, each of which raises important questions concerning the formation and change of the various usages as well as the passing on of melodies (Example 3).

The Gradual of Kassa ${ }^{32}$ (now Košice) belongs to the peripheral codices with remarkable external influences (see Example $4 b$ ). It is strange that it displays certain markedly Esztergom-related features (apart from the Alleluia, the Communion as well). Another special occurrence of the melody is in the Gradual of Wroclaw ${ }^{33}$ from the $15^{\text {th }}$ century (see Example 4c); its later written appendix contains not only the Alleluia but the entire Proper of the Transfiguration, what is more, in a form identical with that of the Bakócz Gradual. For lack of additional intermediate sources, it cannot be established whether it was borrowed from Esztergom or not. In spite of its late origin, the third case corroborates the Esztergom origin. It is not surprising that the material of the feast occurs in the $18^{\text {th }}$-century Gradual of Zagreb (MR 6) ${ }^{34}$ in its proper place, but it is all the more astonishing that it agrees almost completely with the melodies of the Bakócz Gradual (see Example $4 d$ ). ${ }^{35}$ This leads us to conclude that the compiler of the Gradual MR 6 had sources at his disposal as late as the $18^{\text {th }}$ century that could pass on not only Esztergom's crystallized medieval tradition but its late, no more embedded developments as well (Example 4).

Further changes of form of the Alleluia Candor est lucis can be met as late as the $17^{\text {th }}$ century. András Szántós $17^{\text {th }}$-century manuscript ${ }^{36}$ has preserved a lot of Esztergom traits but the Strigonian melodies for Transfiguration do not belong to them: of the first-mode variant of the Alleluia no antecedent has been found so far. The Pauline Graduale Romanum of Újhely ${ }^{37}$ represents the most special and

32. H-Bn Clmae 172a, 172b.

33. PL-WRu M 1194.

34. HR-Zmk MR 6.

35. About the ambivalent character of the Gradual MR 6, retrospective on the one hand, whereas modern on the other, see: Orsolya Csomó, "Traditionalism and New Influences in an 18th-Century Gradual of the Zagreb Cathedral with a Special Focus on the Allelluia Repertory," in Cantus Planus Study Group of the International Musicological Society. Papers read at the 16th meeting, Vienna, Austria, 2011, ed. Robert Klugseder (Wien: Verlag Brüder Hollimek, 2012), 96-101.

36. H-Bu A 114, f $93 \mathrm{v}$.

37. H-Bu A 115. 


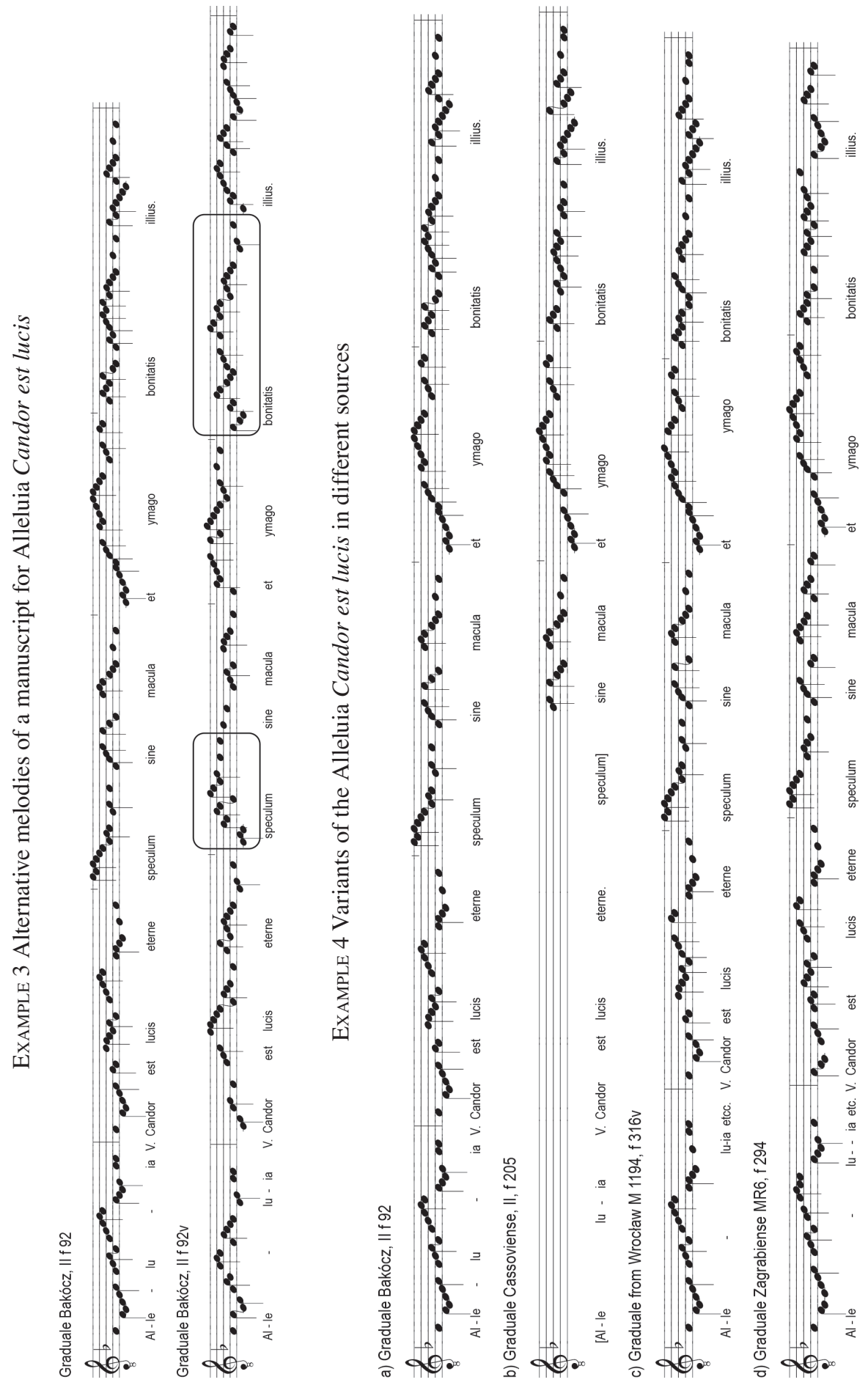




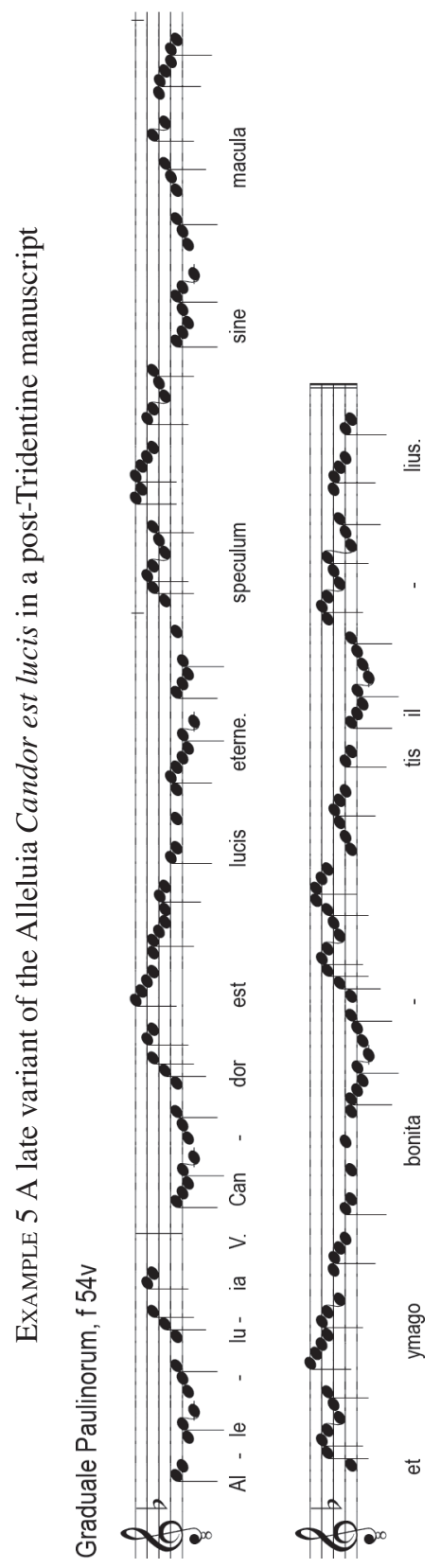


complex case (see Example 5). ${ }^{38}$ The Feast of the Transfiguration has also a Roman Proper. Since the Order of St. Paul decided to accept the Roman Missal and Breviary in 1600, it is quite natural that the Sátoraljaújhely source should contain their text. As it is well-known by now, the source relied, as far as melodies are concerned, on medieval antecedents in several places, ${ }^{39}$ which shows especially in the matter of the Alleluia Candor est lucis. The melody is not identical with any of the earlier ones though reminds exceedingly of numerous earlier examples of the group $O$ consolatrix. While the Paulines had taken over the Esztergom melodies almost note by note in the majority of cases earlier, they preserved in this instance not a single melody, but willy-nilly the essence of a common and in the Hungarian tradition particularly popular style of melody itself (Example 5). ${ }^{40}$

The Proper melodies for the Feast of the Transfiguration lend themselves for examining the mode of shaping of the late repertoire, the system and possibilities of its handing down in the context of sources. The manifold individual cases not only show that the melodic material was shaped with increasing freedom in this late period but provide also a kind of imprint of the actual musical taste. At the same time, the lack of uniformity marks not only the last stage of the formation of a tradition. As the late introduction of the feast left no time for the crystallization, maturing or selection of its material, it appears in the sources in that unstable, transitory state that must have formed an organic part of the development process of numerous medieval Propers as well.

38. About the special character of this manuscript cf. Janka Szendrei, "Der Ritus tridentinus und die paulinische Tradition im Ungarn des 17. Jahrhunderts: Kompromiss, Kontrafaktur, Modifikation," in The Past in the Present. Papers Read at the IMS Intercongressional Symposium and the $10^{\text {th }}$ Meeting of the Cantus Planus Budapest \& Visegrád, 2000, ed. László Dobszay (Budapest: Liszt Ferenc Academy of Music, 2003), 329-352.

39. As Janka Szendrei demonstrated (see the previous footnote), the compiler of the manuscript combined the new Roman texts with old Strigonian melodies, primarily in case of Alleluias.

40. There is another manuscript originating in a religious order that contains the Alleluia Candor est lucis, moreover, a complete Proper for Transfiguration. The manuscript was written in 1516 and belonged to the Premonstratensian Nuns in Szeged. In 1981 Janka Szendrei referred to it as a lost manuscript, see A magyar középkor hangjegyes forrásai [Notated Manuscripts of the Hungarian Middle Ages] (Budapest: Institute for Musicology, 1981), 44-45. In 2004 the manuscript turned up in the Franciscan Monastery of Szombathely. See Sándor Lázs, "A megkerült Pozsonyi Kódex és Szegedi Antifonale, valamint két elkallódott kézirat" [The newly-found "Pozsonyi Kódex" and "Szegedi Antifonale", and two further lost manuscripts], Magyar Könyvszemle 122 (2006/2), 141-161. Although the Premonstratensian Order was founded from abroad and followed primarily foreign models, in the late Middle Ages - as this manuscript testifies - its communities and sources were not culturally independent from the local environment. The manuscript contains chants for Hungarian saints and the complete cycle for Transfiguration, written with Messine-Gothic Hungarian mixed notation. The melodies are independent ones, the Alleluia belongs to the family of the F mode melodies, its closest variant is perhaps the exuberant Alleluia in the Graduale Bakócz. 